\title{
HUBUNGAN KOMUNIKASI INTERPERSONAL DOKTER GIGI MUDA DENGAN MUTU PELAYANAN DITINJAU DARI KEPUASAN PASIEN DI KLINIK FAKULTAS KEDOKTERAN GIGI UNIVERSITAS ANDALAS
}

\author{
Rahmi Agvanesia', Zulkarnain Agus $^{2}$, Eni Rahmi ${ }^{1}$ \\ ${ }^{1}$ Fakultas Kedokteran Gigi Universitas Andalas \\ ${ }^{2}$ Fakultas Kedokteran Universitas Andalas
}

\begin{abstract}
Background: Interpersonal Communication is a communication skill and it is one of the competencies that must be had by dentists, therefore, FKG UNAND has been trying to implement this soft skill by implementing it into curriculum. Patient satisfaction on interpersonal communication is thought to be one of the factors that determines the quality of a health service. The aim of the study is to determine whether there is a relationship between interpersonal communication of co-assistant students with service quality based on patient satisfaction at FKG UNAND clinic. Method: The study was an observational cross-sectional analytic approach. The sampling was simple random and the number of subjects were 90 respondents. The instruments used in this study were questionnaires consisting of 17 questions; they were 12 questions regarding interpersonal communication and 9 questions regarding patient satisfaction on service quality. Results: The result of chi-square test for interpersonal communication of co-assistant students-patient is $p=0.041[p<0.05]$. This shows that there is a significant relationship between interpersonal communication of co-assistant students with service quality based on of patient satisfaction at FKG UNAND Clinic. Conclusion: There is relationship between interpersonal communication of co-assistant students and service quality based on of patient satisfaction at FKG UNAND Clinic.
\end{abstract}

Keywords: interpersonal communication of co-assistant students, service quality, patient satisfaction

Affiliasi penulis: ${ }^{1}$ Fakultas Kedokteran Gigi Universitas Andalas Korespondensi: eni rahmi, email: eni.rahmi@dent.unand.ac.id

\section{PENDAHULUAN}

Salah satu soft skills yang harus diterapkan disetiap lembaga tinggi pembelajaran adalah keterampilan komunikasi. ${ }^{1}$ Keterampilan komunikasi interpersonal sangat penting pada bidang kesehatan termasuk dalam mengedukasi kesehatan gigi dan mulut. Dokter gigi yang ingin berhasil harus mampu mengkomunikasikan pesan ke berbagai pasien. ${ }^{2}$ komunikasi yang baik antara dokter-pasien dapat mencegah terjadinya tuntutan-tuntutan malpraktek dari masyarakat kepada dokter/dokter gigi. ${ }^{3}$ Standar kompetensi dokter gigi di Indonesia (SKDGI) telah mengatur perihal keterampilan komunikasi yang harus dimiliki setiap lulusan pendidikan dokter gigi. Pada SKDGI domain satu dinyatakan bahwa salah satu kompetensi utama lulusan pendidikan dokter gigi adalah mampu melakukan komunikasi, informasi, dan edukasi secara efektif dan bertanggung jawab baik secara lisan maupun tertulis dengan pasien, keluarga atau pendamping pasien serta masyarakat, teman sejawat, dan profesi kesehatan lain yang terkait. ${ }^{4}$ Fakultas 
Kedokteran Gigi Universitas Andalas (FKG UNAND) berusaha mewujudkan kompetensi keterampilan komunikasi dalam salah satu misinya, yaitu menyelenggarakan pendidikan yang berkualitas untuk menghasilkan dokter gigi yang profesional dan bermoral tinggi serta mampu menghadapi persaingan global. Lulusan pendidikan dokter gigi FKG UNAND diharapkan dapat memenuhi kebutuhan Indonesia dan bahkan dunia akan sumber daya manusia yang tidak hanya unggul dalam teori tetapi juga terampil dalam komunikasi.

Dalam meningkatkan proses dan hasil pelayanan medik gigi yang optimal, maka dibutuhkan evaluasi mutu pelayanan di klinik pendidikan FKG UNAND. Dua aspek yang menentukan tingkat mutu pelayanan kesehatan adalah aspek medis dan non-medis. Aspek medis mencakup kesembuhan penyakit yang diderita, efek samping yang dialami, kematian pasien, dan kepuasan pasien. Aspek non-medis adalah pelayanan kesehatan yang diselenggarakan sesuai dengan kode etik dan standar pelayanan kesehatan yang ditetapkan, antara lain pengetahuan pasien, kemantapan pasien terhadap pelayanan yang diselenggarakan, dan kepuasan pasien. Dalam kedua aspek tersebut terdapat indikator kepuasan pasien. $^{5}$
Komunikasi dokter-pasien

terbukti mempengaruhi kepatuhan pengobatan dan meningkatkan kepuasan pasien. $^{6-10}$ Komunikasi yang berpusat pada pasien dapat meningkatkan efisiensi pelayanan dengan berkurangnya prosedur diagnosis dan rujukan. ${ }^{11}$ Komunikasi yang baik antara dokter-pasien menunjukkan hubungan emosional dan kesehatan fisik yang lebih baik, penurunan gejala yang lebih bermakna dan kontrol nyeri yang lebih baik pada penyakit kronis yang meliputi tekanan darah, kadar glukosa darah dan kontrol yang lebih baik. ${ }^{12}$ Sikap empati yang ditunjukkan oleh dokter kepada pasien dalam proses komunikasi interpersonal akan menimbulkan kepuasan dan kepatuhan pasien pada pengobatan. ${ }^{13}$ Berdasarkan uraian di atas, maka penulis tertarik untuk melakukan penelitian mengenai hubungan komunikasi interpersonal dokter gigi muda dengan mutu pelayanan ditinjau dari kepuasan pasien di klinik FKG UNAND.

\section{METODE}

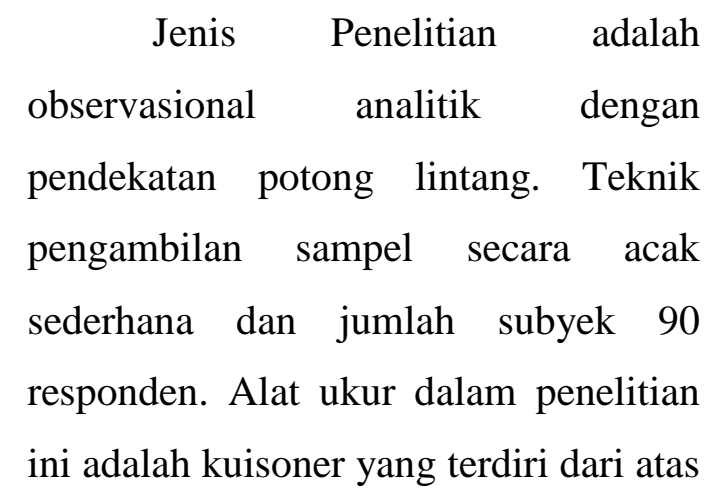


17 pertanyaan, yaitu 12 pertanyaan mengenai komunikasi interpersonal dan 9 pertanyaan mengenai kepuasan pasien terhadap mutu pelayanan.

\section{HASIL DAN PEMBAHASAN}

Berdasarkan karakteristiknya, responden penelitian ini dapat dideskripsikan menurut umur dan jenis kelamin. Umur responden berkisar antara 18-50 tahun, dengan rerata 25,42 $\pm 8,288$ tahun. Dalam paparan kategorik, responden terbanyak pada kategori umur 18-27 tahun (80\%). Hasil ini menggambarkan bahwa diantara pasien dewasa pengunjung klinik FKG UNAND, didominasi oleh kelompok umur dewasa muda. Jenis kelamin responden didominasi oleh jenis kelamin perempuan.

Mayoritas responden $(95,6 \%)$ memiliki persepsi bahwa komunikasi interpersonal dokter gigi muda di klinik FKG UNAND sesuai harapan. Hanya sedikit responden yang memberikan penilaian sangat buruk (sangat tidak setuju) mengenai aspek komunikasi interpersonal. Bahkan terdapat cukup banyak responden yang memiliki persepsi yang sangat baik (sangat setuju) mengenai aspek komunikasi interpersonal tersebut. Hal ini sejalan dengan penelitian Asdawati, dkk tentang gambaran kepuasan pasien dalam pelaksanaan komunikasi efektif dokter di RSUD kota Makassar. Hasil penelitiannya menunjukkan 93,5\% pasien puas dan $6,5 \%$ pasien tidak puas dengan komunikasi efektif dokter di Instalasi Rawat Jalan RSUD Kota Makassar. ${ }^{16}$ Namun, berbeda dengan hasil penelitian Hilal Ariadi tentang persepsi pasien terhadap mutu pelayanan dokter ditinjau dari karakteristik dan mutu pelayanan di instalasi rawat jalan RSI Sunan Kudus tahun 2005. Hasil penelitiannya menunjukkan bahwa menurut pasien hubungan interpersonal dokter-pasien di RSI Sunan Kudus 21\% tidak baik, $67 \%$ memiliki persepsi biasa saja, 9\% memiliki persepsi baik, dan 3\% memiliki persepsi sangat tidak baik. ${ }^{17}$

Mayoritas responden $(95,6 \%)$ memiliki persepsi bahwa mutu pelayanan di klinik FKG UNAND memuaskan. Hal ini dapat dilihat dari 5 indikator mutu pelayanan yang ditanyakan kepada pasien/responden, dan hanya sedikit yang memberikan penilaian buruk mengenai mutu pelayanan di klinik FKG UNAND tersebut. Hal ini berarti tingkat kepuasan pasien terhadap mutu pelayanan di klinik FKG UNAND memenuhi salah satu standar pelayanan pasien rawat jalan. Menurut Keputusan Menteri Kesehatan Republik Indonesia Nomor 129 tahun 2008 tentang standar pelayanan minimal rumah sakit, salah satu standar pelayanan pasien rawat 
jalan adalah kepuasan pelanggan lebih dari $90 \% .^{18}$

Hal ini sesuai dengan temuan Asmidar dan Andi tentang studi pelayanan berdasarkan kepuasan pasien di Klinik Gigi dan Mulut RSUP Dr. Wahidin Sudirohusodo Makassar. Hasil penelitiannya menunjukkan bahwa mutu pelayanan di klinik gigi dan mulut RSUP Dr. Wahidin Sudirohusodo pada tahun 2007 adalah baik. ${ }^{19}$ Hal ini juga bertolak belakang dengan hasil penelitian Hilal Ariadi tentang persepsi pasien terhadap mutu pelayanan dokter ditinjau dari karakteristik dan mutu pelayanan dokter di instalasi rawat jalan RSI Sunan Kudus tahun 2005. Hasil penelitiannya menunjukkan bahwa $81 \%$ pasien merasa mutu pelayanan di RSI Sunan Kudus tidak sesuai harapan dan $19 \%$ pasien merasa mutu pelayanan sesuai harapan. 17

Komunikasi interpersonal dokter gigi muda secara statistika memiliki hubungan yang bermakna dengan mutu pelayanan di klinik FKG UNAND dengan nilai $p=0,041$. Hal ini memberi makna bahwa dengan komunikasi interpersonal dokter gigi muda-pasien yang baik dapat memenuhi kepuasan pasien sehingga meningkatkan mutu pelayanan di klinik FKG UNAND.

Hal ini sesuai dengan hasil penelitian Hilal Ariadi tentang persepsi pasien terhadap mutu pelayanan dokter ditinjau dari karakteristik dan mutu pelayanan dokter di instalasi rawat jalan RSI Sunan Kudus tahun 2005. Hasil penelitiannya menunjukkan bahwa persepsi pasien terhadap mutu pelayanan dokter rawat jalan salah satunya dipengaruhi oleh hubungan interpersonal antara dokter dan pasien. ${ }^{16}$ Begitu pula dengan penelitian Daniel Budi Santoso tentang hubungan komunikasi interpersonal dengan kepuasan pasien pemakai gigi tiruan lengkap. Dari penelitian tersebut didapatkan adanya hubungan positif antara komunikasi interpersonal dengan kepuasan pasien pemakai gigi tiruan lengkap. ${ }^{20}$ Hal ini juga sesuai dengan hasil penelitian Asdawati, dkk, tentang gambaran kepuasan pasien dalam pelaksanaan komunikasi efektif dokter di RSUD kota Makassar tahun 2014, yang menunjukkan terciptanya interaksi komunikasi yang baik antara dokter dan pasien sebagai salah satu faktor yang menyebabkan pasien puas terhadap pelayanan yang diberikan. ${ }^{17}$

Komunikasi yang baik antara dokter gigi muda dan pasien dalam proses pengobatan menjadi penyebab kepuasan pada mutu pelayanan di klinik FKG UNAND. Komunikasi dokter gigi muda memiliki pengaruh yang sangat kuat terhadap persepsi mutu pelayanan di klinik FKG UNAND. Hal ini dikarenakan pasien di klinik datang 
dengan sengaja untuk mendapatkan pelayanan kesehatan, mereka mungkin telah meluangkan waktu, menunda pekerjaan dan aktivitas lainnya untuk bisa memperoleh pelayanan. Sambutan penerimaan oleh dokter gigi muda, sikap empati, keterbukaan, keseriusan, dan sikap menghargai dokter gigi muda dalam melayani akan sangat kuat dalam membentuk persepsi terhadap mutu pelayanan di klinik FKG UNAND. Komunikasi interpersonal yang baik akan membuat pasien merasa apresiasi yang baik pula, yang akhirnya membuat mereka senang, bahkan puas dengan pelayanan kesehatan yang diterima. ${ }^{21}$

Hal ini sesuai dengan temuan Roberts, Roter, Trummer, Lee, dan Thorne bahwa komunikasi dokter dan pasien dapat meningkatkan kepuasan pasien. ${ }^{6-10}$ Kim dan Park menyatakan bahwa sikap empati yang ditunjukkan pasien dalam komunikasi interpersonal akan menimbulkan kepuasan dan kepatuhan pasien pada pengobatan. ${ }^{13}$ Menurut Saragih, komunikasi yang baik akan membentuk persepsi yang lebih positif terhadap kepuasan mutu pelayanan. $^{21}$

Dalam melakukan penelitian ini memiliki keterbatasan. Keterbatasan yang terjadi pada penelitian ini adalah penelitian ini tidak memperhitungkan karakteristik pasien di klinik FKG UNAND. Kebanyakan pasien yang datang adalah pasien yang dibawa oleh dokter gigi muda, sehingga subjektifitasnya menjadi tinggi. Selain itu, pertanyaan dan jawaban yang tertera dalam kuesioner penelitian kemungkinan belum dapat menampung seluruh fakta dan pendapat maupun harapan responden/pasien. Hal ini karena kepuasan pasien merupakan sesuatu yang bersifat subjektif sehingga sulit untuk diukur. Meskipun penelitian ini memiliki keterbatasan, namun penelitian ini diharapkan tetap dapat memberikan manfaat.

\section{SIMPULAN}

Berdasarkan uraian sebelumnya diperoleh data bahwa tingkat komunikasi interpersonal dokter gigi muda dengan pasien ditunjukkan dengan, 95,6\% responden merasa puas dan $4,4 \%$ responden tidak puas. Tingkat mutu pelayanan dokter gigi muda ditinjau dari kepuasan pasien di klinik FKG UNAND 95,6\% responden merasa puas dan 4,4\% merasa tidak puas. Sehingga, dapat disimpulkan bahwa terdapat hubungan komunikasi interpersonal dokter gigi muda dengan mutu pelayanan ditinjau dari kepuasan pasien di klinik FKG UNAND.

\section{KEPUSTAKAAN}

1. Jain, Vishal. Importance of Soft Skills Development in Education.2009. 
2. Felton A, Chapman A, Felton S. Basic Guide to Oral Health Education and Promotion. New Delhi : Wiley-Blackwell. 2009.

3. Levinson W. In context: physicianpatient communication and managed care. J Med Pract Manage 1999; 14(5): 226-230

4. Konsil Kedokteran Indonesia. Standar Kompetensi Dokter Gigi. Jakarta : 2006.

5. Pohan IS. Jaminan Mutu Layanan Kesehatan Dasar-Dasar Pengertian dan Penerapan. Jakarta : EGC; 2013.

6. Roberts KJ. Physician-Patient Relationships, Patient Satisfaction, and Antiretroviral Medication Adherence Among HIV-Infected Adults Attending a Public Health Clinic. AIDS Patient Care and STDs. 2002; 16(1): 43-50. doi:10.1089/108729102753429398. Roter DL, Frankel RM, Hall JA, Sluyter D. The Expression of Emotion Through Nonverbal Behavior in Medical Visits. Mechanisms and outcomes. J Gen Intern Med 2006; 21 Suppl 1:S2834

7. Trummer UF, Mueller UO, Nowak P, Stidi T, Pelikan JM. Does Physician-patient Communication that Aims at Empowering Patients Improve Clinical Outcome? A case study. Patient Educ Couns 2006; 61(2):299-306

8. Lee YY, Lin JL. Linking Patients's Trust in Physicians to Health Outcomes. Br J Hosp Med (Lond) 2008; 69 (1):42-46.

9. Thorne SE, Hislop TG, Armstrong EA, Oglov V. Cancer Care Communication: The Power to Harm and the Power to Heal? Patient Educ Couns 2008; 71(1):3440.

10. Stewart M, Brown JB, Donner A, Mc Whinney IR, Oates J, Weston WW et al. The Impact of Patientcentered Care on Outcomes. J Fam Pract 2000; 49(9): 796-804.

11. Stewart M, Meredith L, Brown JB, Galajda J. The Influence of Older Patient-physician Communication on Health and Health Related Outcomes. Clin Geriatr Med 2000; 16(1): 25-36.

12. Kim SS, Park BK. Patient-perceived Communication Styles of Physicians in Rehabilitation: The Effect on Patient Satisfaction and Compliance in Korea. Am J Phys Med Rehabil 2008; 87(12):9981005

13. Supriyanto S, Ernawati. Pemasaran Industri Jasa Kesehatan Yogyakarta : ANDI;2010.

14. Adhani, Rosihan. Etika dan Komunikasi Dokter-Pasien- 
Mahasiswa. Banjarmasin: Grafika

Wangi Kalimantan. 2014.

15. Asdawati, Sidin AI, Kapalawi I. Gambaran Kepuasan Pasien Dalam Pelaksanaan Komunikasi Efektif Dokter di RSUD Kota Makassar. 2014.

16. Ariadi, Hilal. Persepi Pasien Terhadap Mutu Pelayanan Dokter Ditinjau dari Karakterstik dan Mutu Pelayanan Dokter di Instalasi Rawat Jalan RSI Sunan Kudus Tahun 2005 [Tesis]. Semarang: Universitas Diponegoro; 2005.

17. UPKP2. Standar Minimal Dalam Pelayanan Unit Rawat Jalan dan Rawat Inap di Rumah Sakit [Internet]. 2013.[cited 20 November 2014]; Available from:http://upkp2.batangkab.go.id

18. Asmidar A, Abdullah AZ. Studi Mutu Pelayanan Berdasarkan Kepuasan Pasien di Klinik Gigi dan Mulut RSUP Dr. Wahidin Sudirohusodo Makassar [Tesis]. Makassar : Universitas Hasanuddin, 2007.

19. Santoso DB. Hubungan Antara Komunikasi Interpersonal dengan Kepuasan Pasien Pemakai Gigi Tiruan Lengkap [Tesis]. Yogyakarta: Universitas Gajah Mada; 2013.

20. Saragih, Somauli. Hubungan Kualitas Pelayanan Dan Kepuasan
Pasien Dengan Kujungan di Balai Pengobatan Gigi Pukesmas Kota Pekanbaru [Tesis]. Medan : Universitas Sumatera Utara, 2008. 